International Journal of Agriculture, Environment and Bioresearch

Vol. 4, No. 03; 2019

ISSN: $2456-8643$

\title{
BLOOD PROFILES AND ITS RELATIONSHIP WITH MILK PRODUCTION TRAITS IN AGROPASTORAL GOATS
}

\author{
"Sam, I.M., Essien C. A. And Ekpo, J. S. \\ Department of Animal Science, Faculty of Agriculture, Akwa-Ibom State University, Akwa-Ibom State, Nigeria. \\ http://doi.org/10.35410/IJAEB.2019.1623
}

\begin{abstract}
This study was conducted to evaluate blood profiles and it relationship with milk production traits in agropastoral goats. Atotal of 250 does whose parity were between 1-6 and average weight of $28.84 \mathrm{~kg}$ were used for this study, the animals were milked twice a week, and milk production traits investigated were average daily yield (ADY), total yield (TY), peak day (PD), peak yield (PY), lactation length (LL), and last day yield (LDY). Five milliliter (5ml) of blood was collected from each of the sampled animals by jugular venipuncture, using needle and syringe. $2 \mathrm{mls}$ of each blood sample were poured into a bijou bottle containing ethylene diamine tetra-acetic acid (EDTA) for hematological evaluation which were Pack Cell volume (PCV) and haemoglobin concentration $(\mathrm{Hb})$. The remaining samples were allowed to coagulate to produce sera for blood chemistry analysis. The separated serum samples were properly labeled and stored at $-20 \circ \mathrm{C}$ till further analysis. Serum samples were analyzed for different biochemical profile namely sodium (Na), total protein (TP) albumin, globulin and glucose. Correlations between blood profiles and milk production traits were obtained using Statistical Analysis system. The results indicated that the agropastoral goats were within the range of normal reference values for goats $(28.47 \%$ PCV, 9.49g/dl Hb136.40mmol/L Na, 64.44g/l Total protein, $31.12 \mathrm{~g} / \mathrm{l}$ Albumin, $33.12 \mathrm{~g} / \mathrm{l}$ globulin and $4.44 \mathrm{~g} / \mathrm{l}$ glucose). The correlation between blood constituents and milk production traits revealed that $\mathrm{PCV}, \mathrm{Hb}$ and glucose were positively correlated with milk yield traits. Thus suggesting that increase or improvement in these blood parameters may increase milk production in goats.
\end{abstract}

Keywords: Blood profiles, Milk yield, Relationship and Agropastoral goats

\section{INTRODUCTION}

Goats form the most important group of milk producing animals after dairy cattle in both temperate and tropical agriculture. The dairy goat industry is rapidly gaining importance throughout the world.

Blood parameters have been widely used to determine genetic diversity in animal population. The concentration of metabolites in animal blood is an important indicator associated with health and production (Casasuset al., 2002). The development of different traits in animals depends on the good order of complex biochemical processes each of them functioning under a rigorous genetic control (Mariana et al., 2006; Sam, 2012). 
In lactating animals, blood biochemical variables including total protein are important indicator of metabolic activity (Karapehilivanet al., 2007). In addition some blood metabolites including total protein and glucose are positively and significantly correlated with milk yield in goat (Anwar et al., 2015) and cow (Lean et al., 1992). Milk production depends on mammary development and the availability of nutrients especially glucose. Increasing glucose availability could promote milk production by enhancing lactose synthesis. There is paucity of information in Nigeria on the relationship that exists between blood profiles and milk production traits in goats. Therefore, the objective of this study was to evaluate blood profiles in agropastoral goats and its relationship with milk production traits.

\section{MATERIALS AND METHODS Study Area}

The Study was carried out inJigawa State which is within the Sudan savannah zone of NorthWest Nigeria. Jigawa State falls within latitude $11^{\circ}-13^{\circ} \mathrm{N}$ and Longitude $8^{\circ}-10^{\circ}$, E; the State has an altitude of between $400-600 \mathrm{~m}$ above sea level. The mean annual rainfall varies from 500 $\mathrm{mm}$ to $1000 \mathrm{~mm}$. The mean daily maximum and minimum temperatures are $35^{\circ} \mathrm{C}$ and $19^{\circ} \mathrm{c}$ respectively (Magashi, 2011).

\section{Animals and their Management}

The goats used for this study were under semi intensive system of management. The animals were taken out to graze every morning from $8.00 \mathrm{am}$ to $5.00 \mathrm{pm}$ by children and were penned at night. The goats were given water and supplement which included groundnut haulms, cowpea haulms and dry grasses, before setting out for grazing every morning. Each animal was tagged with a number for individual identification.

\section{Data Collection}

A total of 250 agropastoral goats that comprised of Red Sokoto goats, Sahel goats, Kano Brown and their Crosses (whose parities were between 1-6 and average body weight of $28.84 \mathrm{~kg}$ ) were hand milked twice a week and the milk obtained per each milking per doe was measured using graduated plastic beakers. Milking of does commenced from day 7 postpartum and lasted till the milk yield was less than $100 \mathrm{ml}$. Kids were separated from their dams at $6.00 \mathrm{pm}$ on the evening preceding the day of milking. On the test day, the two halves of the udder of each lactating doe were hand-milked for all herds from 06.00 to 08.00 AM and the milk yield was recorded to the nearest gram. The average of the total volume of milk collected for the two test days was taken as the average daily yield of the doe for that week.

\section{Milk yield characteristics}

Milk yield characteristics were measured as follows:

Average Daily Yield (ADY): - As average of all test day yields within the milking period

Initial Yield (IY): - As milk yield at day 7 postpartum

Total Yield (TY): - As milk production during the lactation period up to the point where the production of the doe dropped below 100ml;

Peak Yield (PY): - As the highest test day yield during the lactation period;

Peak day (PD): - As the day corresponding to the highest yield within the lactation period;

Lactation Length (LL): - As the period from kidding to the point when the milk yields of the doe falls below $100 \mathrm{ml}$. 
Vol. 4, No. 03; 2019

ISSN: $2456-8643$

\section{Blood Collection and Preparation for analysis}

Five milliliter $(5 \mathrm{ml})$ of blood was collected from each of the sampled animals by jugular venipuncture, using needle and syringe. $2 \mathrm{mls}$ of each blood sample were poured into a bijou bottle containing ethylene diamine tetra-acetic acid (EDTA) for hematological evaluation which were Pack Cell volume (PCV) and haemoglobin concentration $(\mathrm{Hb})$. The remaining samples were allowed to coagulate to produce sera for blood chemistry analysis. The separated serum samples were properly labeled and stored at $-20^{\circ} \mathrm{C}$ till further analysis. Serum samples were analyzed for different biochemical profile which included; Sodium (Na), total protein (TP), albumin, globulin and glucose. The potassium and sodium concentrations in the blood were determined by colorimetric method using spectrophotometer. Glucose level was determined after enzymatic oxidation in the presence of glucose oxidase. Measurement of albumin was based on its quantitative binding to the indicator 3, 3, 5, 5 - tetrabromo- $\mathrm{m}$ cresol sulphonephthalein (bromocresol green, BCG).Globulin concentration was calculated from total protein and albumin, by subtracting albumin from total protein.

\section{Statistical Analysis}

The data collected from this study were analyzed using General Linear Model (GLM) procedure of SAS (SAS, 2000). Correlation coefficients and test of significance were done.

\section{RESULTS AND DISCUSSION}

The means and coefficient of variation (CV) for concentration of blood biochemical profiles are presented in Table 1. Average PCV, $\mathrm{Hb}, \mathrm{Na}$, total protein, albumin, globulin and glucose were $28.48 \%, 9.49 \mathrm{~g} / \mathrm{dl}, 136.40 \mathrm{mmol} / \mathrm{l}, 64.44 \mathrm{~g} / \mathrm{L}, 31.12 \mathrm{~g} / \mathrm{L}, 33.12 \mathrm{~g} / \mathrm{L}$ and $4.44 \mathrm{~g} / \mathrm{L}$, respectively. All the blood biochemical constituents measured were within the range of normal values of serum electrolytes of goats as reported by (Rodostiset al., 2000). The percentage of PCV (28.47\%) in this study was very close to the $29.4 \%$ obtained by Daramolaet al. (2005) in WAD goats. However, this value is higher than $25.7 \%$ obtained in Red Sokoto goats (Tambuwalet al., 2002). Earlier reports in Baladi goats (Azab and Abdel - Maksoud 1999) showed PCV values of $27.25 \%$. The $\mathrm{Hb}$ concentration in this study $(9.49 \mathrm{~g} / \mathrm{dl})$ was within the range of normal values obtained in Red Sokoto goats (7-15g/dl) (Daramolaet al., 2005). This is an advantage in terms of oxygen carrying capacity of the blood, which may lead to better functioning and performance of these animals.

The Na concentration obtained in this study $(136.40 \mathrm{mmol} / \mathrm{L})$ was within the range reported by Daramolaet al. (2005) as $135.1 \mathrm{mmol} / \mathrm{l}$ of $\mathrm{Na}$ in West African dwarf goats. Tambuwalet al., (2002) reported $138.0 \mathrm{mmol} / \mathrm{l}$ in Red Sokoto goats. Sodium makes up about $93 \%$ of the basic mineral elements in the blood serum and is chief cation regulating blood $\mathrm{pH}$ (Swartz, 2010). The ability of muscles to contract is dependent on proper sodium concentration. Therefore, these indigenous goats could be said to have normal sodium concentration in the blood. Total protein in this study (64.44g/l) was within the range reported by Tambuwalet al. (2002), in Red Sokoto goats. Proteins are the basic components of enzymes, many hormones, antibodies and clotting agents. They act as transport substances for hormones, vitamins, minerals, lipids and other materials. In addition, proteins help balance the osmotic pressure of the blood and tissue (Kaslow, 2011). Total protein in the blood which represents the sum of albumin and globulin is a very strong indicator of the health status of the animals; low albumin is a sign of poor health. 
The glucose concentration of $4.44 \mathrm{~g} / \mathrm{l}$ determined in this study was within the normal reference values, although a little higher than reports of Zubcic (2001). He established that glucose level decreases with age of goats, and most of the animals in this study were between ages $2-6$ years which probably explains the high concentration of glucose. Glucose is the major precursor of lactose synthesis in the mammary gland, and lactose is the major carbohydrate and osmolyte of milk which controls milk volume and its concentration (Shahbazkialet al., 2010).

Phenotypic correlation between blood biochemical profiles and milk yield characteristics in goats are presented in Table 2. PCV had significantly $(\mathrm{P}<0.05)$ low, but positive correlation with ADY, TY and IY. It also had positive though not significant relationship with PD and PY, but a negative correlation with LL and LDY. Hb had a positive and significant $(\mathrm{P}<0.05)$ relationship with TY, non- significant, though positive relationship with PD and PY but negative correlation with IY, LL and LDY. Na concentration had negative correlation with all the milk yield characteristics measured. Total protein had positive and significant $(\mathrm{P}<0.05)$ relationship with IY and LL, positive though not significant correlation with ADY and TY, but negative correlation with PD, PY and LDY. Albumin had negative correlations with all the milk yield characteristics measured. Globulin had negative correlations with ADY $(r=-0.101)$ and PY $(r=-0.066)$, but had very low and positive correlation with every other trait measured. Glucose had a positive and significant $(\mathrm{P}<0.05)$ correlation with LL, positive though not significant relationship with ADY, TY, IY and LDY. The positive correlation between milk yield characteristics and glucose had earlier been reported by Chladek and Machal (2002) who studied the relationship between blood plasma glucose and milk production in Holstein cows. However contrary to these reports, Blum et al., 1983 who observed that plasma glucose levels in cows with a high milk yield were significantly lower than cows with a low milk yield. The correlation between glucose and LL could be attributed to the fact that lactose which is the major precursor of glucose controls milk volume (Shahbazkialet al., 2009). The negative and very low correlation between milk yield characteristics and albumin had earlier been observed by Hassan et al., (1986) in Egyptian Baladi goats.

Breed of does had non-significant $(\mathrm{P}>0.05)$ effect on all the blood biochemical profiles measured except $\mathrm{Na}$, total protein and albumin (Table 3). Na concentrations in Kano brown was significantly $(\mathrm{P}>0.05)$ higher than Sahel, but statistically similar to other breeds. The Sahelian goats had the highest total protein and was significantly $(\mathrm{P}<0.05)$ higher than the concentration in the crosses, but similar to the concentration in the Red Sokoto and Kano Brown.Ghahfarokhi and Samani (2018) indicate that performance and biochemical parameters of animalswith different genetic potentials and breeds are different.

There were weak correlations among the blood constituents (Table 4), however, PCV showed a positive and significant correlation with $\mathrm{Hb}$. This explains that increase in PCV led to increase in $\mathrm{Hb}$ concentration.

\section{CONCLUSION}

It was concluded that blood profiles of the agropastoral goats were within the range of normal reference values for goats. The positive correlation between glucose and ADY, TY, and IY indicate that if glucose level is increased, it will influenced milk production positively.

\section{REFERENCES}


Anwar, M. M., Ramadar, T. A. and Taha, T. A. (2012). Serum metabolites, milk yield and physiological

response during the first week after kidding in Anglo-Nubian, Angora, Baladi and Damascus goats

under subtropical conditions. Journal of Animal Science 90:13 pp 4795 - 4806.

Azab, M. E and Abdel-Maksoud, H.A (1991), changes in some haematological and biochemical parameters during per-partum and post - Partum periods in Female Baladi Goats.Small Ruminant Research, 34, 77-85.

Blum, J. W., Kunz, P., and Leuenberger, H.(1983).Thyrooid Hormones, Blood Plasma Metabolites and

Haematological Parameters in Relationship to milk yield in Dairy Cows. Animal Production 36:93-

104

Casasus, I., Sanz, A., Vilalba, D., Ferrer, R. and Revilla R. (2002).Factors Affecting animal performance

during grazing season in a mountain Cattle cattle production system. Journal of Animal

Science80:1638 - 1651 .

Daramola, J.O., Adeloye, A.A., Fatoba, T.A. and Soladoye, A.O. (2005). Haematological and biochemical parameters of West African Dwarf goats. Livestock Research for Rural Development.

17(8): $1-8$.

FAOSTAT (2008).http://faostat.fao.org/default.aspx

Ghahfarokhi, S. M., and Samani, A. D.(2018) Bool Metabolic Profile Test at Dairy cattle farms as useful tools for Animal Health Management. Bulgarian Journal of Veterinary Medicine

3: $1-20$

Hassan G. A., El-Nouty, F. D., Samak, M. A. and Salem, M. H. (1986). Relationship between milk

production and some blood constituents in Egyptian Baladi goats. Beitr Tropical

LandwirtschVeterinarmed, 24(2):213-219.

Karapehlivan, M. E., Atakisi, O. A., Yucayurt, R. and Pancarci, S. M. (2007). Blood biochemical parameters during the lactation and dry period in Tuj ewes. Small Rum. Res. 73:267-271

Kaslow, J. E. (2011).Serum Proteins.www.drkslow.com

Magashi, I. (2011). Jigawa State in Brief.www.Jigawastate.com

Mariana, R., Elena, G., Georgescu,S. E., Vatasscu- Balcan, R. and Marieeta C. (2006). Study of some

biochemical markers in a population Romanian spotted cattle. Archiva Z Zootechnical, 9:2631.

Oduye, O. O. and Adadevoh, B. K. (1976). Biochemical Values of Apparently normal Nigerian sheep. Nigerian Veterinary Journal, 5(1): 43-50.

Radostits, O.M., Gay, C.C., Blood, D.C. and Hinchcliff, K.W. (2000).The haematologicalvalues for

cattle, sheep, goatsand pigs. Veterinary Medicine, 9th edn,W.B. Saunders, London, pp. 18191822. 
SAS, (2000).Statistical Analysis system, Version 8.0 SAS Institute Inc. Cary North Carolina, USA.

Shahbazkial, H. R. Aminlari, M., Tavasoli, A., Mohammadnia, A. R. and Cravador, A. (2010). Associations among milk production traits and glycosylated haemoglobin in diary cattle; importanceoflactose synthesis potential. Veterinary Research Communication, 34:1-9. Swartz, H .(2010). Importance of salt in the diet of sheep and goats. Goat and sheep news, volume 1,issue 12010 ; www.lincolnu.edu.

Tambuwal, F.M., Agale, B. M. and Bangana, A. (2002).Haematological and Biochemical values of

apparently healthy Red Sokoto goats. Proceeding of the $27^{\text {th }}$ Annual Conference Nigerian Society of Animal Production (NSAP), March, 77-21, 2002, FUTA Akure, Nigeria, pp. 50:53. Zubcic, D. (2001). Some biochemical parameters in blood of grazing German improved fawn goats from

Istria, Croatia. VeterinarskiArchiv, 71 (5): 237-244. 
Table 1: Blood profiles of agropastoralgoats (Mean \pm se)

\begin{tabular}{|llllll|}
\hline Characteristic & No & Mean \pm se & CV & Min & Max \\
\hline PCV $(\%)$ & 250 & $28.48 \pm 0.28$ & 15.03 & 4.00 & 42.00 \\
$\mathrm{Hb}(\mathrm{g} / \mathrm{dl})$ & 250 & $9.49 \pm 0.09$ & 15.58 & 4.66 & 14.00 \\
$\mathrm{Na}(\mathrm{Mmol} / \mathrm{L})$ & 250 & $136.40 \pm 0.42$ & 6.02 & 125.00 & 141.00 \\
$\mathrm{TP}(\mathrm{g} / \mathrm{L})$ & 250 & $64.44 \pm 0.49$ & 12.21 & 46.00 & 94.00 \\
Albumin $(\mathrm{g} / \mathrm{L})$ & 250 & $31.12 \pm 0.37$ & 18.32 & 20.00 & 51.00 \\
Globulin $(\mathrm{g} / \mathrm{L})$ & 250 & $33.12 \pm 0.60$ & 28.72 & 13.00 & 65.00 \\
Glucose (g/l) & 250 & $4.45 \pm 0.04$ & 14.92 & 2.80 & 6.60 \\
\hline
\end{tabular}

$\mathrm{PCV}=$ pack cell volume, $\mathrm{HB}=$ haemoglobin concentration, $\mathrm{Na}=$ sodium, $\mathrm{TP}=$ Total protein

Table 2: Coefficients of Phenotypic Correlation between Blood Biochemical Profiles and lactation Characteristics in Goats

\begin{tabular}{|llllllll|}
\hline Characteristics & PCV & $\mathrm{Hb}$ & $\mathrm{Na}$ & $\mathrm{TP}$ & Albumin & Globulin & Glucose \\
\hline ADY & $0.284^{*}$ & $0.289^{*}$ & -0.024 & 0.166 & -0.051 & -0.101 & 0.122 \\
TY & $0.247^{*}$ & $0.291^{*}$ & -0.218 & 0.006 & -0.028 & 0.019 & 0.194 \\
IY & $0.291^{*}$ & -0.251 & -0.176 & $0.401^{*}$ & -0.034 & 0.049 & 0.218 \\
PD & 0.176 & 0.149 & -0.099 & -0.038 & -0.038 & 0.018 & -0.151 \\
PY & 0.092 & 0.096 & -0.036 & -0.112 & -0.055 & -0.066 & -0.194 \\
LL & -0.381 & -0.360 & -0.193 & $0.720^{* *}$ & -0.023 & 0.076 & $0.346^{*}$ \\
LDY & -0.075 & -0.075 & -0.177 & -0.002 & -0.012 & 0.005 & 0.059 \\
\hline
\end{tabular}

$* \mathrm{P}<0.05, \mathrm{ADY}=$ Average Daily Yield, TY = Total Yield, IY = Initial Yield, PD = Peak Day, $\mathrm{PY}=$ Peak Yield, $\mathrm{LL}=$ Lactation Length, $\mathrm{LDY}=$ Last Day Yield, $\mathrm{PCV}=$ pack cell volume, $\mathrm{HB}$ =haemoglobin concentration, $\mathrm{Na}=$ sodium, $\mathrm{TP}=$ total protein

Table 3: Mean values ( \pm se) of Blood biochemical Profiles of Goats according to breed

\begin{tabular}{|c|c|c|c|c|c|c|c|c|}
\hline Factor & & PCV & $\mathrm{HB}$ & $\mathrm{Na}$ & $\mathrm{TP}$ & Albumin & Globulin & Glucose \\
\hline \multirow[t]{2}{*}{ Breed } & Crs & $26.87 \pm 0.51$ & $8.96 \pm 0.18$ & $133.67 \pm 0.77^{\mathrm{ab}}$ & $64.09 \pm 0.91^{\mathrm{b}}$ & $31.71 \pm 0.67^{\mathrm{ab}}$ & $32.56 \pm 1.10$ & $4.720 \pm 0.08$ \\
\hline & Sh & $26.67 \pm 2.57$ & $8.89 \pm 0.89$ & $125.67 \pm 387^{b}$ & $73.00 \pm 4.55^{\mathrm{a}}$ & $35.67 \pm 3.34^{\mathrm{a}}$ & $37.33 \pm 5.53$ & $4.800 \pm 0.39$ \\
\hline & RS & $29.28 \pm 1.99$ & $9.77 \pm 0.77$ & $135.26 \pm 0.52^{\mathrm{ab}}$ & $64.45 \pm 0.61^{\mathrm{ab}}$ & $31.36 \pm 0.45^{\mathrm{ab}}$ & $33.09 \pm 0.85$ & $4.325 \pm 0.06$ \\
\hline
\end{tabular}




$\begin{array}{llllllll}\mathrm{Kb} & 25.60 \pm 2.10 & 8.53 \pm 8.53 & 139.20 \pm 3.00^{\mathrm{a}} & 66.20 \pm 3.53^{\mathrm{ab}} & 25.60 \pm 2.59^{\mathrm{b}} & 32.56 \pm 4.29 & 4.200 \pm 0.31\end{array}$

$* \mathrm{P}<0.05 ; \mathrm{a}, \mathrm{b},=$ column means under the same factor with different superscripts differ significantly, $\mathrm{Crs}=$ crosses $; \mathrm{Sh}=$ Sahel $; \mathrm{RS}=$ Red Sokoto $\mathrm{Kb}=$ Kano brown; $\mathrm{PCV}=$ pack cell volume; $\mathrm{HB}=$ haemoglobin concentration; $\mathrm{Na}=$ Sodium; $\mathrm{TP}=$ Total protein

Table 4: Coefficients of Phenotypic Correlation amongst Blood Biochemical Profiles in Goats

\begin{tabular}{|lllllll|}
\hline Characteristics & PCV & HB & Na & TP & Albumine & Globulin \\
\hline Hbcon & $0.962^{* *}$ & & & & & \\
Na & 0.058 & 0.041 & & & & \\
TP & -0.102 & -0.069 & 0.125 & & & \\
Albumine & 0.064 & $0.510^{* *}$ & 0.057 & $0.454^{*}$ & & \\
Globulin & -0.120 & -0.085 & 0.067 & $0.796^{* *}$ & $-0.563^{*}$ & \\
Glucose & -0.105 & -0.106 & -0.154 & -0.029 & 0.147 & -0.117 \\
\hline
\end{tabular}

$* \mathrm{P}<0.05, * * \mathrm{P}<0.01, \mathrm{PCV}=$ pack cell volume, $\mathrm{HB}=$ haemoglobin concentration, $\mathrm{Na}=$ sodium, $\mathrm{TP}=$ total 